\title{
An Analysis of Literary Representations of Iranian Men in Diasporic Iranian Literature
}

\author{
Sanaz Fotouhi, University of New South Wales
}

In 1987 Betty Mahmoody published her memoir, Not Without My Daughter. It recounts her life as an American woman married to an Iranian doctor in the USA. In 1985, in the wake of the 1979 Iranian revolution and at the height of the Iran-Iraq war, Dr Mahmoody, who had encountered racial discrimination at work, decided to travel to Iran for two weeks with Betty and their daughter, Mahtob. After much convincing, Betty was persuaded to undertake the trip. Iran, however, was not what she had imagined. She depicts the country as a dirty desert with basic facilities and 'primitive' customs that she does not understand. Expecting to return to the USA after two weeks, Betty learned on the day of their planned return that her husband had been fired from his job in the USA and had decided to stay in Iran indefinitely. It appears this had been his plan all along. As Betty protests, Mahmoody becomes violent and abusive. When she attempts to run away, he separates her from Mahtob and imprisons her. But she manages to sneak out and meet people who help her. After eighteen months of abuse and mistreatment, Betty and Mahtob escape through the mountains into Turkey, where they seek refuge at the US consulate.

Mahmoody's memoir has been one of the most successful bestsellers of its genre since its publication. As of 2010, Not Without My Daughter had sold 11 million copies, and had been translated into numerous languages. To date, it is still listed as one of the top 100 books in chain bookstores alongside classics such as Catcher in the Rye and Sense and Sensibility. I begin this paper with Mahmoody's book, and its success, because it

PORTAL Journal of Multidisciplinary International Studies, vol. 11, no. 1, January 2014.

Stigma and Exclusion in Cross-Cultural Contexts Special Issue, guest edited by Annie Pohlman, Sol Rojas-Lizana and Maryam Jamarani.

ISSN: 1449-2490; http://epress.lib.uts.edu.au/ojs/index.php/portal

PORTAL is published under the auspices of UTSePress, Sydney, Australia. 
has had consequences for the way modern Iranian culture, particularly Iranian masculinity, has been perceived in the West. As Shahram Khosravi argues, 'the construction of Iranian men's “primitive masculinity” started in the late 1980s. The most conspicuous and influential mediawork operation has undoubtedly been Not Without My Daughter ... [which] has created a widespread stereotype of the Iranian man' (2009: 599).

While Mahmoody's representation may have exerted considerable influence on contemporary representations of Iranian men, this kind of portrayal of Iranian and Middle Eastern masculinity dates further back to early encounters of the West with the Middle East. In the West, both historically as subjects of Western imagination and more recently as members of the Western polity, Iranian and other Middle Eastern men have long been subjected to ambivalent representations. In Western travelogues, for example, as Faegheh Shirazai has argued, the Middle Eastern man is portrayed 'as something lesser, not quite as a real man,' as either a despot or a victim, as 'either domineering patriarchal or oppressed by colonial power' (2010: 6). More recently, these dichotomies have been reflected in Western films that portray Middle Eastern and Iranian men as the 'bad guys,' the terrorists at fault. The Middle Eastern man, then, has been portrayed as either the main antagonist or as a simplified, one-dimensional character constructed to fulfil an expected role.

Interestingly, the ambivalence of Iranian masculinity has not been constructed by Western representations alone. Rather, in recent times numerous books by Iranian women writers in English have been replicating the stereotypical Orientalist depiction of Iranian men found in Mahmoody's Not Without My Daughter. In many of these accounts, Iranian men are depicted hypervisibly and negatively as violent fanatics and sexual deviants; at the same time, ambivalently, they may be rendered almost invisible. Given this ambivalence in Iranian women's writing it is notable that there is a dearth of Iranian men's voices within the larger framework of diasporic Iranian writing in English and in the recent scholarship that surrounds it. While Iranian women's fiction and memoirs have received significant attention from publishers, readers, reviewers, and scholars, Iranian men's narratives have been largely ignored. But such narratives do exist. In my research into the representation of and works by Iranian men in English since the 1979 revolution, I discovered that Iranian male authors have published over 
sixty-five memoirs and books of fiction in English. Yet, unlike books by Iranian women, many of which have become part of popular English-language literary discourse in the West, very few of the men's accounts have replicated that success. Furthermore, while Iranian women's narratives have attracted much scholarly attention, there is again a dearth of reviews of, let alone academic engagement with, works written by Iranian men.

Cognisant of this background, my aim here is to address the scant scholarly and public attention paid either to diasporic Iranian men's narratives or to the representation of Iranian masculinity. Given that Western perceptions of Iranian men and masculinity have primarily been constructed through narratives by diasporic Iranian women writers, I first consider how Iranian masculinity has been represented in relation to feminist discourses. I argue that Iranian women's narratives, usually filtered through a critique of patriarchy and/or Orientalist feminist discourses, coupled with Iranian women's tendency towards self-Orientalization in their own writing, have contributed to Iranian men's simultaneous hypervisibility and invisibility in diasporic Iranian literature written in English. Second, I examine the increasing popularity of diasporic Iranian men's narratives and argue that their writing stems from a desire to critique conventional understandings of Iranian masculinity. Drawing on Kelly Oliver's theories of subjectivity in Witnessing (2001), and situating male diasporic Iranian male writing in specific sociopolitical settings, I examine the various strategies that male writers have employed to represent and reconstruct Iranian masculinity and their own individual sense of identity.

\section{Male hypervisibility/invisibility and female self-Orientalisation}

The current hypervisibility and invisibility of Iranian men can be traced back to the legacy of Orientalist discourses that historically described Middle Eastern Muslim men as autocrats who lock up women. 'Oversexed degenerates,' as Said sardonically puts it in Orientalism, these men are 'capable of cleverly devious intrigues, but [are] essentially sadistic, treacherous [and] low' (1978: 287). In the contemporary epoch, moreover, representations of Middle Eastern masculinity have become synonymous with fundamentalism, and associated with terror, rage and savagery. Yet it should not be forgotten that in Iran the onset of modernization in the early decades of the twentieth century produced Western educated men who encouraged the public presence of women in society, thereby enabling stereotypical images of Iranian masculinity to shift slightly. 
However, following the 1979 Islamic revolution and the US Embassy hostage crisis (1979-1981), more negative connotations were renewed and reconfirmed for the Western gaze. As the Western world watched in horror 'wild-eyed' Iranians shook their fists in the air and sent death messages to the USA (Scott 2000: 178). By taking US diplomatic representatives hostage, Iranian men regained their position as 'devilish savages of Islam' (Scott 2000: 178). As Khosravi argues (2009: 599) this primitive image of Iranian masculinity was based on notions of fundamentalist Islam and promoted through various media outlets. ${ }^{1}$ That image, heightened later by $9 / 11$ and the ensuing 'War on Terror,' has perpetuated the hypervisibility of Iranian masculinity in the West.

The position of Iranian men, however, is even more complicated given that until recently most understandings of Iranian masculinity in the West were mediated and constructed through a feminist perspective. Lahoucine Ouzgane observes that 'in the last three or four decades, scholarly attention to gender issues in the Middle East and North Africa has been focused almost exclusively on a quest to understand femininity: what is it and how it is made and regulated?' (2006: 1). Steeped in an Orientalist vision of the Middle East that rendered Muslim women as at once 'victims of religious dogma' (Bahramitash 2006: 223) and oppressed by dominant patriarchal discourses, Middle Eastern women have become subjects of recognition and study in the West. Middle Eastern women's narratives, particularly after $9 / 11$ and in the wake of new conflicts between Middle Eastern regimes and the West, were embraced by Western readers. Consequently the Western publishing industry realised the marketability of these books, and since 2001 hundreds of titles by and about Middle Eastern women have been published in the West, with a significant proportion by and about Iranian women.

This timely sociopolitical interest at a time of political tensions between Iran and the West has also encouraged specific modes of reading. In Rethinking Global Sisterhood (2007), Nima Naghibi outlines her interest in analysing 'how particular kinds of (often contradictory) representations of the Persian woman as abject, as repressed, and, paradoxically, as licentious [has] become consolidated as unquestioned "truths" in

\footnotetext{
${ }^{1}$ In Islamophobia Peter Gottschalk and Gabriel Greenberg demonstrate how the image of the Iranian man evolved during and after the Iranian revolution and the hostage crisis through cartoons in popular US newspapers that depicted Imam Khomeini 'and the Islamic revolutionaries of Iran as crazy, backward, and violent' (2008: 124).
} 
dominant Western and Iranian feminist discourses' (2007: x). A seminal text that critiques and outlines the relationship between Western white feminism and that of the 'third world,' in this case Iranian women, Naghibi explains how the idea of 'global sisterhood' has functioned in the past and present to benefit Western women at the expense of the Other. Naghibi explores this relationship through analysis of texts by Western women about Iranian women, and suggests that such representations have also influenced Iranian feminism and Iranian women's representation of themselves. She positions her argument around the current situation of political instability and military conflict across the Middle East, and concludes that such texts have influenced recent Western declarations of war across the Middle East in the name of liberating its women.

Although these types of representation have been common in the West for many decades, particularly in the works of diasporic Iranian women writers, the origins of these representations date back to the introduction of concepts of Western modernity, including feminism, to Iran in the late nineteenth and early twentieth centuries. In his insightful Refashioning Iran: Orientalism, Occidentalism and Historiography, Mohammad Tavakoli-Targhi (2001) proposes that much of what informs the modern narrative of Iranian history is influenced by Western and Eurocentric notions of modernity and 'occidental rationality.' He argues that 'whereas Europeans reconstituted the modern self in relation to their non-Western Others, Asians and Africans [and Middle Easterners] began to redefine their self in relation to Europe, their new significant Other' (2001: 4). At the heart of this definition was a 'binary opposition' influenced heavily by colonial and Orientalist language that defined what was constituted modern - that is Western — and what was not - that is Middle Eastern.

In the early 1900s a prominent signs of difference between what was modern and what was not was defined by the condition of Iranian women, particularly their position, status and visibility in Iranian society and public life. These differences were marked by how Iranian women dressed, which thus came to signify Iran's backwardness not only in the eyes of the West but also from the perspective of certain groups of western educated Iranian modernists in the early decades of the twentieth century. As TavakoliTarghi states, 'for Iranian modernists, viewing European women as educated and cultured, the veil became a symbol of backwardness. Its removal, in their view, was essential to the advancement of Iran and its dissociation from Arab-Islamic culture' 
(2001: 54). Although these ideas were not entirely welcomed by traditionalist Iranians, they were influential enough to construct a specific class within Iranian society in which women were given new forms of freedom. With new models of modernisation, Iranian women had the opportunity to be educated and, despite being in small numbers, for the first time, in the early decades of the 1900s they became part of the public sphere. This not only exposed women to alternative concepts of gender relations, particularly those driven by newly imported concepts of Western feminism; it also gave Iranian women the ability to comment actively and challenge masculine and patriarchal social norms. As early as the 1920s, then, Iranian women were publishing their opinions and views on different aspects of Iranian society, including on concepts of veiling and unveiling. ${ }^{2}$

For Nasrin Rahimieh 'this conceptualisation ... has informed [much of] Iran's understanding of its own history' (2003: 148). One can argue that it also informs much of diasporic Iranian women's contemporary writing, especially when representing Iranian gender relations and Iranian masculinity. A survey of diasporic women authors published since the 1980s reveals a list dominated by elite Iranian families. Azar Nafisi, for example, the author of Reading Lolita in Tehran (2004), is the daughter of one of Tehran's mayors during the Shah's regime; her mother was one of the first women representatives of the parliament during the Shah's regime. Sattareh Farman-Farmaian, the narrator of Daughter of Persia (1996), is a Qajar Princess with a father who insisted on his daughter's education, even permitting her to go to the USA as one of the first Iranian women to travel alone outside Iran in the early 1900s, at a time when her friends were being taken out of middle school by their parents to be married. Lily Monadjemi, author of Blood and Carnations (1993) and A Matter of Survival (2010), is the descendent of Naser Al-Din Shah, one of the Shahs of Persia (1848 to 1896) who is widely regarded as responsible for the country's nineteenth century encounter with modernity. Marjan-Satrapi, creator of the Persepolis comic series, is a descendent of a Qajar monarch. Davar Ardalan, the author of My Name is Iran (2008), is the daughter of Laleh Bakhtiar, one of the most prominent Iranian-American women scholars, and a translator into English of the Koran from a feminist perspective. Similarly, Shusha Guppy, the author of many books including The Blindfold Horse (1988), was also a songwriter, singer and filmmaker, and the daughter of a famous Iranian theologian who

\footnotetext{
${ }^{2}$ In Women with Moustaches and Men Without Beards (2005), Afsaneh Najmabadi identifies the earliest and most significant contributions that Iranian women have made to feminist discourse in Iran.
} 
sent her to Paris in 1952 to study oriental languages and philosophy when she was only seventeen. The list is not exclusive; but it does indicate how much of what is being written about Iran outside Iran is being informed by people from a historically privileged class of Iranian society. This is not to deny that women of non-aristocratic backgrounds, such as Marina Nemat, Firoozeh Dumas, Gina Nahai and Susan Pari, also contribute to the discourse. However, by virtue of living outside Iran and writing in English, they too could be deemed to belong to this privileged class of educated Iranians.

I highlight this class factor because the social situation, personal experiences, and education of many of the women who are now cultural leaders and representatives of Iranian experiences in diaspora are very much Westernised or influenced by Western concepts of modernity. This influence, as Rahimieh (2003) and Tavakoli-Targhi (2001) both argue, is steeped in Orientalist notions and dichotomies that were carried across with Western notions of modernity in the early part of the twentieth century. For Rahimieh 'Orientalist discourses ... underwrite the history of modern Iran' (2003: 148). However, the Islamic revolution in the late 1970s that re-emphasised the East/West and gender dichotomies, also created unresolved contradictions not only between Iran and the West but also between Iranians themselves. As Said tells us, 'if all told there is an intellectual acquiescence in the images and doctrines of Orientalism, there is also a very powerful reinforcement of this in economic, political, and social exchange: the modern Orient, in short, participates in its own Orientalising' (1978: 325). This means that Iranians themselves, whether as pro-government proponents from Iran who emphasise the differences between Iran and the West, or as educated diasporic writers writing about the perils of life for Iranians under the Islamic regime, or as even defenders of women's rights, may be implicated inevitably in the politics of what Rahimieh calls ‘self-Orientalisation' (2003).

On this basis, therefore, if some diasporic writers, particularly women writers, are involved in this process of self-Orientalisation, what impacts does this process have on the representation of Iranian men and forms of masculinity produced by their work? As Naghibi puts it, 'in representing Persian women, [many] draw on what Foucault has called the "already-said," or rather the repressed "never-said" of manifest discourse. The truth of Iranian women's representation as abject, veiled subjects is thus further entrenched by the self-referentiality of the already-said of colonial discourse' (2007: 
xvii). Many Iranian women writers, coming from a privileged, educated echelons of Iranian society, to some degree identify with this discourse. As Naghibi reminds us:

\begin{abstract}
the Western woman, modeled on an Enlightenment figure of autonomous subjecthood, contrasts herself in each instance to the Persian woman, represented as the devalued Other against which Western woman consolidates herself. Privileged Iranian women in the nineteenth centuries also participated in the discursive subjugation of their working-class Persian counterparts. By positioning the Persian woman as the embodiment of oppressed womanhood, Western and elite Iranian women represented themselves as epitomical of modernity and progress. (2007: xvii)
\end{abstract}

I believe that this approach operates even now, particularly amongst diasporic Western educated women and that this self-Orientalising tendency among diasporic Iranian women has a direct influence on how Iranian masculinity is perceived and represented in the West. A glimpse at the range of memoirs and fictional works by diasporic Iranian women writers reveals that, in most cases, women are depicted as oppressed and lacking freedom, mostly at the hands of various male members of their family or by patriarchal society at large. Women's dystopia, it seems, has been created by the men in their lives. Rarely do we come across likeable and rounded male characters or even a loving male/female relationship. More often than not when men are present they are representative of specific types of masculinity: patriarchs, abusers, sexual deviants, and religious fundamentalists.

Most notable of all such types in numerous texts is the controlling patriarchal father who can become abusive and against whose authority no other member of the family dares speak. In Nahid Rachlin's memoir, Persian Girls (2006), for instance, her father is represented as the all-controlling patriarch who always has the last word. Although Rachlin, with her brothers' support and influence, manages to leave for the USA to study, her father's decisions lead to her sister Pari's unsuccessful marriage to an abusive man and their subsequent divorce. The father's insistence on a second marriage for Pari confines her under the power of a mentally unstable man who eventually commits her to a mental institution. The marriage is responsible for her depression and death in mysterious circumstances. Similarly, in Zoe Ghahramani's Sky of Red Poppies (2010), Roya's father, a powerful landowner, is a fearsome figure who makes sure his children, especially his girls, do as they are told. When Roya's sister disobeys and becomes involved in politics he ships her off to the USA. Similarly, in Mani Shirazi's Javady Ally (1984), we are taken into the lives of Homa and her mother, who live under the constant fear of a verbally and physically abusive father. 
Azar Nafisi's Reading Lolita in Tehran (2004) features male figures who appear in different oppressive forms in the lives of the girls in the book club. The seven girls seem to be living in fear of their domineering brothers, fathers, or other male family members. Nafisi, in fact, introduces each girl in relation to the difficulties she has had with her male family members in getting to the first session of the book club. Sanaz is seen running into Nafisi's house 'harassed, as if she had been running from a stalker or a thief,' after her younger brother, 'the darling of their parents,' who had 'taken to proving his masculinity by spying on her, listening to her phone conversations, driving her car around and monitoring her actions,' had dropped her off with disapproval (2004: 14). Another girl, Nassrin, reveals in a conversation with Nafisi how she finally made it to the book club: 'I mentioned the idea [of attending this book club] very casually to my father, just to test his reaction, and he vehemently disapproved. How did you convince him to let you come? I asked. I lied, she said. You lied? What else can one do with a person who's so dictatorial who won't let his daughter at this age, go to an all-female literature class?' (2004: 17)

Other typical male 'types' who appear across various books are religious fanatics and sexual deviants, or a combination of both. Nassrin in Nafisi's Reading Lolita in Tehran (2004), for instance, reveals how 'her youngest uncle, a devout and pious man,' had sexually abused her while tutoring her. She recounts how 'during those sessions as they sat side by side at her desk, his hands had wandered over her legs, her whole body, as she repeated the Arabic tenses' (2004: 49). Similarly, in Javady Ally (Shirazi 1984), young Homa is abused on the shoulders of a trusted clergyman who volunteers to carry her through crowded demonstrations. As they walk through the crowd, he fondles her through her skirt, pretending to keep her steady on his shoulders.

Although there is no denying that such descriptions may be representative of Iranian women and their lived experiences, the representations of the oppressed Iranian woman as narrated from a position of privilege by Western-educated women also inevitably engender hypervisible stereotypes of Iranian men and masculinity. As Kelly Oliver (2001) argues in Witnessing, her study of the psychology of oppression and subjectivity, both hypervisiblity and invisibility are 'bad visibility' in that neither allow for those represented to be seen or recognized as individuals, let alone speak for themselves. This is an oppressive force, according to Oliver since 'the seeing/being-seen dichotomy 
mirrors the subject/object dualism that is symptomatic of oppression. The seer is the active subject while the seen is the passive object' (2001: 149). As she puts it, 'oppression makes people into faceless objects or lesser subjects. The lack of visage in objects renders them invisible in any ethical or political sense. In turn, subjectivity becomes the domain of domination. Subjectivity is conferred by those in power and empowered on those they deem powerless and disempowered' (2001: 149).

By representing Iranian men in general terms, and without giving them the opportunity to express themselves, Iranian women writers are potentially replicating the kind of oppressive force identified by Oliver while also rendering Iranian men, and alternative aspects of Iranian masculinity, invisible. Furthermore, the majority of such texts are circulated within a Western context where they interrelate and reinforce with the 'antiIranian attitudes ... and anti-Iranian propaganda that began during the hostage crisis' (Mobasher 2006: 101). Moreover, given their 'ignorance [of] and refusal to distinguish pro- and anti-Khomeini Iranians living [outside Iran]' (Mobasher 2006: 101) these books can be seen to further emphasise the hypervisiblity of a highly limited version of Iranian masculinity. Such representations operate in the same way that Derek Stanovsky believes representations of postcolonial masculinity often operate, whereby the 'essentialising and homogenising of masculinity serves to obscure the actual diversity and plurality of lived masculinities' (2007: 495).

Such representations of Iranian men and masculinity could also be regarded as feeding into the post 9/11 discourse of the War on Terror. As Bhattacharyya Gargi reminds us, one of the motives leading to the US declaration of the War on Terror was to liberate women from the oppressive forces of their patriarchal societies: 'the abuse of women and the denial of their public rights has [sic] been used as a marker of barbarism and as indication of societal sickness, a sickness requiring intervention' (2008: 19). When the writer Nafisi, for instance, emphasises how the lives of Iranian women are 'doomed,' and claims that '[Western] novels were an escape from the reality in the sense that we could marvel at their beauty and perfection, and leave aside our stories about the deans and the morality squads on the streets' (2004: 38), her words could be read as fuelling the discourse that appeals to what Spivak famously describes as 'white men saving brown women from brown men' (1994: 93). These assumptions can be interpreted as advocating the War on Terror and US attacks across the Middle East on the basis of 
liberating Muslim women from religiously fanatic men, Iranian or otherwise. Arguably in reaction against this hypervisible oversimplification of Iranian men and masculinity, diasporic Iranian male writers have begun to write back.

\section{Iranian men writing Iranian men}

In 'Displaced Masculinities' Khosravi argues that 'Iranian men's masculine identity has been challenged and renegotiated on the one hand by the Iranian women's struggle for emancipation and on the other hand by the [western] mediaworks' (2009: 591). In response to this, since the early 2000s Iranian men have begun making themselves publically visible in various ways, including through literature. Aware of their ambivalent hypervisible and yet invisible situation, diasporic Iranian men have also begun to narrate their lived experiences of negotiating bifurcated identities. Siamack Baniameri, for example, begins his humorous anecdotal book Iranican Dream (2005), about an average Iranian-American man trying to raise two teenagers by himself, with a chapter entitled 'It Sucks Being Me' with these words: 'Being a Middle EasternAmerican man nowadays is as hard as a stash of beef jerky sitting on top of a pick up truck's dashboard in the Arizona summer heat. You sure grow thick skin' (2005: 3).

In what follows, I highlight, address and analyse some of the books' recurring themes and issues raised by Iranian men in diaspora, situating them against the backdrop of their sociopolitical and historical contexts. In particular, I argue how these books could be read as responses to the hypervisibility of Iranian men and masculinity as constructed by historical Orientalist narratives and Iranian women's Self-Orientalisation in their own texts. I argue that these books, many of which counter the negative stereotypes that have made Iranian men invisible, could be read as postcolonial responses to the marginalising and oppressive forces that have limited the representation of Iranian masculinity. Here, I consider their responses to two specific elements that have greatly contributed to the hypervisibility of Iranian masculinity: the stereotypical representation of Iranian men as religiously violent fanatics and terrorists; and, their representation as sexual deviants. Finally, I argue that this recognition can potentially assist in the reconstruction of Iranian masculinity from the space of hypervisibility and invisibility to that of individual visibility as would be recognisable in a Western context.

\section{Terrorism and the hostage crisis}

For many diasporic Iranian men, the Iranian hostage crisis of 1979 to 1981 - a 
'miniwar,' as Mobasher calls it (2006: 107) between Iran and the USA — and, more recently, the events of $9 / 11,2001$, are key historical events that continue to affect their social position and sense of gendered identity. Both events created tension between how Iranian masculinity is perceived in the West and how Iranian men see themselves in the West, with the hostage crisis arguably having the greatest impact. As Mobasher argues, the hostage crisis operated on the legacy of Orientalist discourses and constructed a new kind of binary opposition between Iran and the USA: '[it] created the first xenophobic anti-Iranian and anti-Islamic reaction with new images of Iran, Islam, and Iranian and other Muslim immigrants as barbaric, uncivilised terrorists - a reaction that continues today' (2006: 112). Consequently many diasporic Iranians, particularly men, were exposed to open discrimination of various kinds, lived with the stigma and shame of being Iranian (Mobasher 2006: 111), which thus 'motivated [them] to cover up their Iranian national origin' (Mobasher 2006: 101). Othered and pushed to the margins, like colonised subjects, it has only been recently that Iranian men have decided to openly deal with the trauma of the hostage crisis and the label of terrorist associated with Middle Eastern men more broadly. Among the many strategies that Iranian men have employed to recontextualise this image, one of the most popular has been through creating a sense of sympathy and human connection with readers.

This is why some writers, such as Said Sayrafiezadeh in his memoir When Skateboards Will Be Free (2009), appeal to a sense of empathy and emotional sympathy to make Iranian men recognisable as individuals. Sayrafiezadeh's memoir recounts his life as the child of socialist parents, an Iranian father-who left to go to Iran to run for president on behalf of the socialist party — and a Jewish-American mother. It recalls not only the difficulties of growing up with a mother who chose to live in self-inflicted poverty and who moved often from place to place, but also the pain of carrying an Iranian name as a middle school student in the USA during the hostage crisis. One of the most emotionally touching memories recalled by Sayrafiezadeh concerns the time his mother finally decides to settle in one place, after which Sayrafiezadeh enters a predominantly black school with clear racial segregation, where white students, after a simple examination, were filtered into more advanced classes as 'scholars' while everyone else stayed with the school's normal curriculum. Soon Sayrafiezadeh finds himself in the scholar classes, where for the first time he befriends a few of his classmates, Daniel and Tab. Daniel is a confident, 'handsome' white boy, who soon takes idealised shape in 
Sayrafiezadeh's mind given that his own physical appearance, with dark bushy eyebrows, clearly marks him as different from other students in the class. Sayrafiezadeh, in recognising his own difference, dreams of looking like Daniel: 'I fantasised about being Daniel, literally, his body taking the place of mine. I was sure the girls liked him, or loved him' (2009: 183). But Daniel 'had one flaw, only one, and that was his blatant and unconcealed racism' (2009: 183). As their friendship grows, and the two boys become closer, the hostage crisis occurs. With Iran mentioned for the first time in school, and as the crisis escalates, Sayrafiezadeh finds himself caught between his unease with his friends' blatant comments about Iranians in Iran and his desire to hide his Iranian identity. However, having been brought up with an opinionated socialist mother, he makes an unruly comment that brings him into the spotlight. When one afternoon Daniel asks him, 'what do you think about the hostage crisis, Said?,' he blurts out: 'I believe the hostages are spies and should be tried for their crimes against the Iranian people ... They deserve what they get' (2009: 193). This comment attracts the attention of his classmates. It marks the end of his friendship with Daniel, and the beginning of a difficult school life where he is beaten up, bullied, and eventually transferred from the scholar class to the class with the black students. Consequently, Sayrafiezadeh becomes hypervisible as a person associated with the hostage crisis. This hypervisibility leads to his invisibility as an individual in school. His old friends now run away from him. Gradually his internal struggle over self-identification renders him invisible even to himself. As he writes:

\footnotetext{
Daniel continued to remain handsome in my eyes. In fact, he became more handsome, while I, in turn became more ugly. This was the unhappy side effect of having first perceived him as my flawless opposite. I grew skinnier, frailer, as he grew more strapping. My features became loud and prominent while his became refined and elegant. I was sure that he would be a movie star when he grew up. It was as if my face was cannibalising the flesh from my body, absorbing it into itself, so that my nose and eyes and eyebrows intensified with each day, growing darker, larger, hairier. It was a hideous face, I was sure, loudly calling attention to itself. Now I avoided mirrors at all costs. (2009: 200)
}

This statement is telling of the psychological operations of hypervisibility / invisibility that affected the Iranian sense of masculinity as a result of the hostage crisis. This is in keeping with Oliver's understandings of subjectivity and identity: subjectivities are constructed intersubjectively, particularly by the way others perceive us and how we perceive ourselves. As she puts it, 'a positive sense of self is dependent on positive recognition from others, while a negative sense of self is the result of negative 
recognition or lack of recognition from others' (2001: 4). She further argues that 'when others respect us as capable of judgment and action, only then can we respect ourselves as autonomous agents' (2001: 5). According to Oliver, in the processes of subjectification 'recognition from the dominant culture is necessary to develop a strong sense of one's own personal and group identity' (2001: 23). Stereotypes and misrecognition based on differences construct an antagonistic relationship and create a kind of 'inferiority complex,' which is the result of the 'internalisation of stereotypes of inferiority' (2001: 24). This inferiority complex, however, operates not only on a psychological level; it can also affect the way we are perceived and perceive ourselves physically. As Oliver argues, 'values of dominant culture are not so much internalised psychologically but forced onto the bodies of the oppressed. The oppressed are chained to the body, represented as unable to think, to reason, to act properly. They are reduced to an egoless, passive body that is at the same time in need of control and discipline' (2001: 24). In short, those who are oppressed also begin to see themselves as physically inferior to the one who is domineering.

Sayrafiezadeh's statements about his own body in When Skateboards Will Be Free would appear to confirm the salience of Oliver's understanding of subjectivity formation. When Sayrafiezadeh is bullied and his friends stop associating with him, he is objectified and oppressed. This lack of intersubjective relationship and recognition affects his sense of subjectivity and he begins to internalise this inferiority. This in turn influences how he sees himself physically, particularly in comparison with Daniel, regarded by Sayrafiezadeh as a representative of the superiority and the power of the dominant culture around him. That in his eyes Daniel grows into a stunning man while he appears thinner and more frail points to the physical internalisation of this kind of inferiority on the physical level. When he stops looking in the mirror he becomes invisible even to himself in what amounts to a loss of identity. This consequently affects his entire life in the USA. Growing up, he turns into a solitary and shy adult with little self-confidence about his appearance. He has occasional self-confessed kleptomaniac tendencies, and gets by working in a low level job for Martha Stewart's company, hoping every day to be recognised for his genius.

This touching and emotionally wrenching account of how Sayrafiezadeh's childhood lead to difficult adult life as a man with Iranian heritage in the USA, reveals how the 
oppression of Iranian men in diaspora has evolved from an overexposed hypervisibile Iranian 'type' to a subjective invisibility as an Iranian diasporic individual. In line with Oliver's arguments, that evolution has made Sayrafiezadeh and other Iranian diasporic men into 'faceless objects, or lesser subjects' (2001: 149). That said, When Skateboards Will Be Free also operates on a level that suggests a break with the oppressive cycle; it offers the author a venue in which to reconstruct and regain a sense of subjectivity by determining his own represented reality. As Oliver reminds us, 'it is not merely being seen, or being recognised between spectacle and oblivion, that makes for an ethical or just relation. Rather ... the oscillation between invisibility and hypervisiblity [is] a matter not so much of being seen but of making one's world' (2001: 150). At the end of his memoir, then, Sayrafiezadeh points to this possibility when he writes, 'It was up to each of us to bear our private miseries alone, until that glorious day in the future when it would all be resolved once and for all, and a perfect world would emerge' (2009: 286). This forward-looking, optimistic statement, coupled with an earlier sentence, 'the truth must not only be truth, it must also be told' (2009: 286), points to the possibility and need for other Iranian men to similarly construct themselves into representational visibility.

\section{Sexuality and romance}

One of the recurring elements in diasporic Iranian men's literature is the theme of sexuality. As noted above, Iranian masculinity in the West has often been framed as a kind of uncontrollable, deviant and violent sexuality. This type of stereotypical representation, which stems historically from Orientalist harem narratives and which is often confirmed and replicated by modern Iranian and Middle Eastern women's narratives, continues to shadow if not overdetermine perceptions of Iranian men in the West today. One of the ways by which writers have attempted to dismantle the stereotype has been to introduce elements of romance and spiritual love into the representation of Iranian male-female relationships. Of the many novels to date that have embraced the romance genre, the most successful so far has been Mahbod Seraji's Rooftops of Tehran (2009), an emotional bildungsroman that follows Pasha, a seventeen year old boy who practically lives on the rooftop of their middle-class family home in Tehran during the summer of 1973, as he falls in love with Zari, the girl next door. Zari is engaged to another young man known as 'Doctor.' Constrained by his sense of loyalty to Doctor, who is a man of values and a good friend, Pasha tries to hide his love 
for Zari. Doctor, who is involved in anti-governmental activities, is taken by the Shah's secret police and eventually killed and Pasha is left behind to console Zari, who also has feelings for him. However, in an act of protest against the Doctor's fate, Zari sets herself on fire in front of the Shah's entourage and is badly burned. To protect Zari and those associated with her act from the government's wrath, her family acts as if she were dead; unbeknownst to Pasha and the outside world, she continues to live at home - in full chador, her face covered - posing as a distant cousin who has moved in with the family to console them after her death. Despite living next to each other for months, the lovers never reunite. At the novel's end, Pasha migrates to the USA to study while Zari's family moves to a distant city.

Everything about this book - the red rose on the cover of the US version; the jokes and games played by Pasha and his friend; the lovers' near kiss on the rooftop; Pasha's temporary insanity at the thought of losing his love - counters the image of Iranian man as sexually deviant and violent. Bringing into fictional space an Iranian man who shares his emotions and feelings challenges the stereotypes that have not permitted Iranian men to be recognised in the West as individual human beings. As Oliver notes, such recognition can break the cycle of oppression and marginality, because 'recognition requires the assimilation of difference into something familiar' (2001: 9). This means that 'the subject recognises the other only when he [sic] can see something familiar in that other, for example, when he can see that the other is a person too' (2001: 9).

Since its publication in 2009, Rooftops of Tehran has had a positive reception among critics, elicited numerous reader reviews and testimonies on popular sites such as Amazon.com, and won numerous awards. Reviewers have praised the novel for its capacity to cross historical and cultural divides, and to present non-stereotypical insights into Iran and its peoples largely absent from the contemporary Iranian novel. The author's website (Seraji 2008) provides a useful archive of many reviews, including the following, which note the novel's challenges to representational orthodoxy vis-à-vis Iranian masculinity: 'Refreshingly filled with love rather than sex, this coming-of-age novel examines the human cost of political repression' (Kirkus); 'Seraji's wonderfully appealing characters, living universal teenage emotional lives of dreams and minor worries, lose their innocence in the brutalities that foreshadow the Iranian revolution' (The Milwaukee Sentinel); and, "'Rooftops of Tehran," calls on America to open its 
eyes and ears to Iran: its people, its pain, its beauty, its love. Hopefully America will listen' (TruthOut). Similarly, Reese Erlich, the author of The Iran Agenda (2007), writes on the author's site: 'You learn a lot about Iranian culture while coming to understand characters with universal appeal.' William Kent Kruegar also writes, 'Thank God for authors like Seraji who show us that no matter how distant apart our worlds may be, in the humanness of our hearts we are all united' (Seraji 2008).

Individual readers, too, have lauded Seraji's novel book. Rooftop's page on Amazon.com is filled with reviews and comments that emphasise how the novel enabled readers to recognise the similarities between themselves and Iranians. One effusive reviewer in particular demonstrates this point when she writes:

\footnotetext{
"Rooftops of Tehran" is much more than a love story. It is an affirmation of shared human experiences. We all dream, love, laugh and cry. We have fears and want good things for our children. Mr. Seraji has given us a glimpse into the unknown and it is up to us to recognise that regardless of religion or culture we are more alike than some would like us to believe. (Rooftops of Tehran n.d.)
}

Such positive responses not only point to the book's success in challenging stereotypes of Iranian men and masculinity, but also begin to break down the national, political and cultural barriers that emphasise an us/them dichotomy. In a diasporic setting this recognition of similarity of human experiences can assist faster integration and acceptance of diasporic Iranians. On a global level, at a time of tension and the ever present threat of war with Iran, such narratives can operate to diffuse tensions by emphasising shared human experiences.

Seraji is not alone in challenging these barriers. Another novel that also presents a romantic understanding of Iranian masculinity is Manoucher Parvin's Avicenna and I: The Journey of Spirits (1996). It tells the story of Professor Pirooz, an Iranian academic who is caught between his home and host cultures and is disenchanted by the social ills of consumerism, random violence and conflict that surround him in New York. When he meets a neighbour, Sitareh Poonia, an Indian woman educated in spiritual philosophy, their love blossoms due to a spiritual connection and their mutual love for the $9^{\text {th }}$ century Iranian mathematician and physician, Avicenna. But Sitareh is murdered. Distraught by her death but guided in his dreams by Avicenna's spirit, Pirooz sets out on a soul-searching journey to Iran, to the city of Hamedan where Avicenna is buried. At Avicenna's mausoleum, however, he meets Sitareh Bastan who bears more than a 
passing resemblance to Sitareh. The two come together through their love for Avicenna and begin a life together.

Avicenna and I operates on several levels to challenge the kind of normalised gender relations associated between Iranian men and women in the West. In her review of the book, Marta Simidchieva argues that Avicenna and I is reminiscent of a Persian 'court romance' (1997: 408). In particular the novel 'evokes a faint echo' of Nezami's Haft Peykar (Seven Beauties), a classic narrative poem from the twelfth century. In Haft Peykar, the Persian King Bahram Gur gains knowledge and spiritual awareness from his seven brides, who come from the far corners of the world. As she compares the two texts, Simidchieva writes that 'in Nezami's romance, as in Parvin's novel, the protagonist's journey of spiritual enlightenment starts in the abode of an Indian beauty and is brought to a close in his union with an Iranian one' (1997: 408).

The book's close intertextual resemblance to a Persian court romance suggests the author's explicit attempt to provide a reconstructed representation of Iranian gender relations. In traditional Persian court poetry, the kind of romantic gender relationship found in Parvin's novel is common and reflective of the romantic tradition in Iranian cultural history. However, in the Western representation of Iranian gender relations, this history has been rendered invisible. By tapping into that tradition and foregrounding the romantic gender relationships so prevalent in Persian court poetry, the novel also functions as a challenge to naturalised Western perceptions of Iranian masculinity. Pirooz's spiritual romanticism, and his soft-spoken nature, are not simply signs of an alternative vision of Iranian masculinity; they also signify a writing back against Orientalist perceptions of Iranian men as violent and sexually aggressive.

Furthermore, Pirooz's close spiritual relationship with both Sitarehs, who act as guides in his spiritual journey, reframes our understanding of gender hierarchy and agency, both in traditional Iranian literature, and in the way the West normally perceives Iranian gender relations. As Simidchieva argues, the novel brings into vision the notion of 'romantic love as a means of spiritual maturation of the male protagonist and the role of the woman as a guide on his journey' (1997: 408). Here however, it must be noted that the although women played a significant role in guiding male protagonists in traditional Persian poetry, and court poetry, as well as in the romance genre more broadly, they were often passive in their roles. Making that point, Simidchieva observes that in 
Parvin's narrative, 'the female characters ... are more assertive than their medieval counterparts' (1997: 408). In Parvin's account, women are not only powerful, active spiritual leaders who guide the male character, they are also sexually more assertive than their male partner: in New York Sitareh Poonia invites Professor Pirooz to her house; in Iran, it is Sitareh Bastan who, after housing Professor Pirooz for a few days, appears in his bedroom in the middle of the night 'like a gentle flame ... in a golden negligee' (1996: 113), catching him by surprise, to initiate passionate, spiritual and sensual lovemaking. Pirooz's reservation, politeness and his initial reluctance to countenance a possible sexual relationship with Sitareh Poonia, combined to challenge reader's expectations of Iranian male sexual dominance and gendered hierarchies.

\section{Conclusion}

In this article I have examined selected representations of Iranian masculinity in diasporic Iranian literature, arguing that Iranian masculinity in diaspora is predominantly constructed in and through Orientalist discourses, and that such constructions continue in Iranian women's self-Orientalising narratives. The representations have generated stereotypes of Iranian masculinity, which have led to the hypervisibility of Iranian men whether in diaspora or in Iran, as well as their simultaneous invisibility in terms of individuated subjectivity. I argue that such narratives deploy a range of strategies to reconstruct and regain a sense of subjectivity and to reframe Western understandings of Iranian gender relationships and hierarchies.

This discussion is an inaugural step in the recategorization and reconceptualization of diasporic Iranian men's narratives as active responses to a history of gendered hypervisibility and invisibility. Further work in this area will need to address the profound narrative shifts about the so-called Iranian experience that occurred in the wake of the controversial Iranian presidential elections in 2009, a period not covered in this article. The post-2009 narratives offer fresh and challenging perspectives for understandings of Iranian identity and masculinity, particularly in light of renewed Western interest in Iranian politics and the Iranian government's relationship with the Iranian people in a region that continues to endure political instability and violence. 


\section{Reference List}

Ardalan, D. 2008, My Name is Iran. Holt Paperbacks, New York.

Bahramitash, R. 2005, 'The War on Terror, Feminist Orientalism and Orientalist Feminism: Case Studies of Two North American Bestsellers,' Middle East Critique, vol. 14, no. 2: 221-235.

Baniameri, S. 2005, Iranican Deam. Online, available: Virtualbookworm.com. [Accessed 15 July 2013].

Erlich, R. 2007, The Iran Agenda: The Real Story of U.S. Policy and the Middle East Crisis. Paradigm Publishers, Boulder, CO.

Farman-Farmaian, S. 1996, Daughter of Persia: A Woman's Journey from Her Father's Harem through the Islamic Revolution. Corgi Press, Auckland.

Gargi, B. 2008, Dangerous Brown Men: Exploiting Sex, Violence and Feminism in the War on Terror. Zed Books, London.

Ghahremani, Z. 2010, Sky of Red Poppies. Turquoise Books, New York.

Gottschalk, P. \& Greenberge, G. (eds) 2008, Islamophobia: Making Muslims the Enemy. Rowman \& Littlefield, Lanham.

Guppy, S. 1988, The Blindfold Horse: Memories of a Persian Childhood. Heinemann, London.

Khosravi, S. 2009, 'Displaced Masculinity: Gender and Ethnicity among Iranian Men in Sweden,' Iranian Studies, vol. 42, no. 4: 591-609.

Mahmoody, B. 1987, Not without My Daughter. Corgi, New York.

Mobasher, M. 2006, 'Cultural Trauma and Ethnic Identity Formation among Iranian Immigrants in the United States,' American Behavioural Scientist, vol. 50, no. 1:100- 17.

Monadjemi, L. 1993, Blood and Carnations. Kirribiri, Eldorado. 2010, A Matter of Survival. Macauley Publishers, Austin.

Nafisi, A. 2004, Reading Lolita in Tehran. Fourth Estate, New York.

Naghibi, N. 2007, Rethinking Global Sisterhood: Western Feminism and Iran. University of Minnesota Press, Minneapolis.

Najmabadi, A. 2005, Women with Moustaches and Men without Beards: Gender and Sexual Anxieties of Iranian Modernity. University of California Press, Los Angeles.

Oliver, K. 2001, Witnessing: Beyond Recognition. University of Minnesota Press, Minneapolis.

Ouzgane, L. 2006, Islamic Masculinities. Zed Books, London.

Parvin, M. 1996, Avicenna and I: The Journey of Spirits. Mazda Publishers, Costa Mesa.

Rachlin, N. 2006, Persian Girls. Tarcher, New York.

Rahimieh, N. 2003, 'Overcoming the Orientalist Legacy of Iranian Modernity: Women's PostRevolutionary Film and Literary Production,' Thamyris/Intersecting, vol. 10: After Orientalism, (ed.) I. E. Boer. Amsterdam \&New York: 147-163.

Rooftops of Tehran, n.d. Page on Amazon.com. Online, available: http:/www.amazon.com.au/RooftopsTehran-Novel-Mahbod-Seraji-ebook/dp/B0020BUX22. [Accessed I July 2014].

Said, E. 1978, Orientalism. Penguin, New York.

Sayrafiezadeh, S. 2009, When Skateboards Will be Free. Dial Press, New York.

Satrapi, M. 2003, Persepolis. Jonathan Cape, London. 2004, Persepolis 2. Jonathan Cape, London.

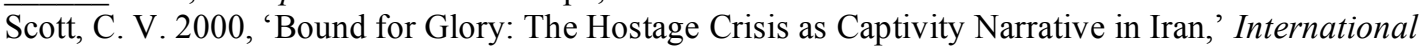
Studies Quarterly, vol. 44, no. 1: 77-88.

Seraji, M. 2008, Rooftops of Tehran: A Novel, author website. Online, available: Rooftopsoftehran.com [accessed 1 December 2013]. 2009, Rooftops of Tehran: A Novel. New American Library, London.

Shirazi, F. 2010, Muslim Women in War and Crisis: Representation and Reality. University of Texas Press, Austin.

Shirazi, M. 1984, Javady Alley. Women's Press, London.

Simidchieva, M. 1997, 'Review of Avecina and I: Journey of the Spirits,' Iranian Studies, vol. 30, no. 3 : 406-408.

Spivak, G. C. 1994, 'Can the Subaltern Speak?' in Colonial Discourse and Post-Colonial Theory: A Reader, (eds) P. Williams \& L. Chrisman. Harvester Wheatsheaf, Hempstead: 90-105

Stanovsky, D. 2007, 'Postcolonial Masculinities,' in International Encyclopedia of Men and Masculinities, (eds) M. Flood, J. Kegan \& B. Pease. Routledge, London: 493-496.

Tavakoli-Targhi, M. 2001, Refashioning Iran: Orientalism, Occidentalism and Histography. Palgrave, New York. 